\title{
Medicine of the Thousand Poems
}

\author{
Jack Coulehan, MD, MPH \\ Center for Medical Humanities, Compassionate Care and Bioethics, Stony Brook University, Stony Brook, NY, USA.
}

J Gen Intern Med 30(3):275-6

DOI: $10.1007 / \mathrm{s} 11606-014-3156-7$

() Society of General Internal Medicine 2015

I "Heart," Elizabeth Lahti tells the story of Delores Hailey, I a desperately ill woman awaiting a second heart transplant. ${ }^{1}$ One day, Delores told Dr. Lahti about a large group of unrelated people named Hailey who gathered for a picnic every year solely to celebrate their common Hailey-ness. In an inspired turn of phrase, Lahti responded, "You are the Delores of the thousand Haileys."

Perhaps the phrase was meant just as a witty retort. But Dr. Lahti took her inspiration a step further by proposing that she and her patient each write a poem using "Delores of the thousand Haileys" as its first line, thus creating an opportunity for both parties to share their deep feelings about Delores' uncertain wait for another heart. An unusual step-perhaps.

The first time I read poems to a medical audience was when I gave Medical Grand Rounds at the Edward Hines, Jr. Veterans Administration Hospital in Chicago more than 25 years ago. I was fraught with anxiety, convinced that listeners would tune out or, even worse, walk out. I visualized my outraged host dragging me offstage with a hook. Nonetheless, I was determined to share my beliefs about the poetry of medical practice. Surprisingly, most attendees not only stayed in their seats, but appeared genuinely interested. These men and women may never have attended a poetry reading, but all had experienced the exuberant joys, as well as the painful inadequacies, of physician-patient communication.

Since then, I frequently read my own poems and those of other physicians as a means of focusing listeners' attention on the poetry accessible to them in patient care. Many physicians respond to poems that touch the emotional core of medical practice and evoke connections that ring true, even though they had not been consciously aware of them. As William Osler wrote, "Nothing will sustain you more potently in your humdrum routine...than the power to recognize the true poetry of life - the poetry of the commonplace, of the ordinary man, of the plain, toil-worn woman, with their loves and their joys, their sorrows and their griefs."

In telling their stories, patients share themselves and expose the deep bonds of humanity we share with them. Clinical practice provides myriad opportunities to experience empathy,

Published online January 14, 2015 solidarity, compassion, and healing. This remains one of the chief rewards of medicine. . How should physicians respond to these human connections?

Relatively few physicians write poetry and even fewer, I imagine, engage their patients in the creative process. Yet in many ways the arts of poetry and medicine are complimentary. Both demand deep attention and careful observation. Both focus on concrete instances - a person, an illness, an event, a feeling - rather than abstractions. Moreover, the physician's skill of empathizing with patients generates a creative act analogous to the poet's exploration of the subject of a poem. Through clinical empathy, a physician seeks to understand the patient's feelings and perspective, and to convey that understanding in an honest, unaffected way.

For decades, medical educators urged caution in responding to the patient's self-disclosure by recommending that physicians adopt a stance of clinical distance or detached concern. They argued that physicians ought to be suspicious of feelings and vulnerabilities, which they claimed might impair objective decision making; in other words, the poetry of healing ought to be suppressed. However, this detached perspective was in direct conflict with a much earlier tradition in medicine that valued engagement with affective, as well as cognitive, dimensions of the physician-patient relationship.

This tradition of engagement has been characterized by a heart metaphor. In the late 18th century, Dr. John Gregory, Professor of Medicine in Edinburgh, urged physicians to develop "the sensibility of heart that makes us feel for the distress of our fellow-creatures." ${ }^{\text {In }}$ 1803, Thomas Percival cautioned his colleagues to "unite tenderness with steadiness in your care of patients and cultivate the tender charity that the moral practice of medicine requires." ${ }^{, 4}$ He warned that emotional detachment can lead to "coldness of heart" and "moral insensibility."4 Osler, too, expressed concern that young physicians not suffer from "hardening (of) the human heart by which we live." 5 Even professors of gross anatomy advised students to "cultivate an affectionate sympathizing spirit."6 Most famously, Dr. Francis Peabody urged his students to commit "time, sympathy, and understanding" to creating a "personal bond" with their patients. ${ }^{7}$ Tenderness, sensibility, an affectionate sympathizing spirit...how different these notions are from detached concern.

How can we cultivate this sensibility in medical education? Most students approach medical school aspiring to become sensitive, compassionate physicians. Yet the "hidden curriculum" tends to undermine these values, and leaves many 
students struggling with a sense of "dehumanization" because they have little opportunity to process emotional or spiritual aspects of their clinical work. ${ }^{8}$ In recent years, some schools have begun to address this deficiency by introducing curricular exercises designed to enhance empathy, emotional intelligence, and self-awareness. Perhaps the most effective of these is based on reflective writing about clinical experiences, followed by group discussion and feedback from faculty mentors.

Because poetry encourages a full spectrum of expressive language, ranging from literal to metaphorical, serious to playful, logical to free associative, it is an especially helpful form of reflective writing. I often ask medical students and residents to translate an emotionally difficult clinical experience into poetry; in essence, to humanize, rather than dehumanize, a troubling situation they may have encountered. Sometimes this involves stepping outside themselves and adopting their patient's perspective. At other times, students capture in poetry an experience of deep satisfaction or connection. Dr. Lahti's story illustrates such a moment. In her case, a chance remark served not only as a stimulus for her own poem, but also an opportunity to engage Delores in a reflective writing exercise. By asking her patient to compose a poem beginning with "Delores of the Thousand Haileys," Dr. Lahti nudged her toward a bit of self-discovery. Only a physician sensitized to the subtleties of the human heart could "see" the potential for mutual benefit in this exchange. By no means an ordinary occurrence, this was one of those moments of empathic connection that physicians occasionally experience. What a privilege!

Of course, medicine is not all poetry. The Romantic poet John Keats, himself trained as a physician, used the term "negative capability" to describe a capacity to hold and cherish opposites in one's mind at the same time, to live "in uncertainties, mysteries, doubts, without any irritable reaching after fact and reason." This is an essential skill in medicine, as well as in poetry. While "reaching after fact and reason" may be a defining feature of scientific medicine, clinicians confront human reality that remains opaque, even after machines and lab tests have yielded their results. If we as clinicians predicate our care entirely on "irritable reaching," or abandon patients because of "uncertainties, mysteries, doubts," we cannot practice effective medicine.

Negative capability opens a pathway into the paradox of physicians being able to move seamlessly between opposites: detached and connected, steady and tender, resilient and vulnerable. In pursuing the steadiness we need in order to master clinical practice, it is tempting to neglect the more difficult project of nourishing tenderness in our relationships with patients - and with ourselves. However, the path of detachment leads us to a less effective place as healers, a place without Osler's "poetry of life.” Dr. Lahti's story reminds us that the alternate path can teach us more about ourselves and our patients that we ever imagined.

Corresponding Author: Jack Coulehan, MD, MPH; Center for Medical Humanities, Compassionate Care and BioethicsStony Brook University, Stony Brook, NY, USA (e-mail:john.coulehan@stonybrookmedicine.edu).

\section{REFERENCES}

1. Lahti E. Heart. J Gen Intern Med, doi:10.1007/s11606-014-3052-1.

2. Osler W. The student life. In: Hinohara S, Niki H, eds. Osler's 'A Way of Life" and Other Addresses with Commentary and Annotations. Durham: Duke University Press; 2001:314.

3. Gregory $\mathbf{J}$. Lectures on the duties and qualifications of a physician. London: W. Strahan and T. Cadell, 1772. In: McCullough LB, ed. Reprinted in John Gregory's Writings on Medical Ethics and Philosophy of Medicine. Dordrecht: Kluwer Academic, 1998.

4. Percival T. From a letter to Thomas Gisborne, as quoted by Robert Baker in Deciphering Percival's Code. In: Robert B, Dorothy P, Roy P, eds. The Codification of Medical Morality. Netherlands: Kluwer Academic Publishers; 2003:196.

5. Osler w. Aequanimitas. In: Hinohara S, Niki H, eds. Osler's 'A Way of Life" and Other Addresses with Commentary and Annotations. Durham: Duke University Press; 2001:23.

6. Morril HL. As quoted in Warner JH, Rizzolo LJ. Anatomical instruction and training for professionalism from the 19th to the 21st centuries. Clin Anat. 2006;19:403-414.

7. Peabody F. The care of the patient. JAMA. $1927 ; 88: 877-882$.

8. Coulehan J. Today's professionalism: engaging the mind, but not the heart. Acad Med. 2005;80:892-898.

9. Keats J. The Complete Poetical Works and Letters of John Keats, Cambridge Edition. Mifflin and Company: Houghton; 1899:277. 